\title{
Cytochrome 2J2 (CYP2J2) Gene Polymorphism in Coronary Artery Disease
}

\author{
GHADA S. SABBOUR, M.D.*; NERMINE H. MAHMOUD, M.D.*; SOMIA A. BAWADY, M.D.*; \\ LAMYAA E. ALLAM, M.D.** and DOAA M.A. ELZOGHBY, M.D.* \\ The Departments of Clinical Pathology* and Cardiology**, Faculty of Medicine, Ain Shams University, Egypt
}

\begin{abstract}
Background: Coronary artery disease is a multifactorial disease where genetic risk factors are targeted by the environmental risk factors leads to disease pathogenesis. CYP2J2 is a monooxygenase which metabolize arachidonic acid into cardioprotective compounds. Genetic polymorphisms in CYP2J2 are common especially CYP2J2*7 (rs890293) which reduce CYP2J2 gene expression and subsequently its cardioprotective effects.
\end{abstract}

Aim of Study: The aim of the present case control study to investigate the relation between CYP2J2*7 (G-50T) (rs890293) gene polymorphism and coronary artery disease (CAD) susceptibility and severity in a cohort of Egyptian individuals.

Patients and Methods: The study was conducted on 50 CAD patients and 50 age and sex-matched apparently healthy individuals. Assay of CYP2J2*7 gene SNP (rs890293) was performed by PCR amplification and Restriction Fragment Length Polymorphism (PCR-RFLP) technique.

Results: Our results revealed that the genotypic and allelic frequencies of G-50T didn't show any statistically significant association neither with the susceptibility of coronary artery disease or with the number of significantly diseased coronaries. Also no statistically significant difference between GG genotypes patients and GT genotypes patients as regard risk factors for CAD.

Conclusions: There was no significant association between CYP2J2*7 gene polymorphism (G-50T) (rs890293) and risk of coronary artery disease and also no association between this gene polymorphism and the severity of CAD in the sample of Egyptian population included in this study.

Key Words: CAD - Cytochrome P450 - CYP $2 J 2 * 7-P C R-$ RFLP.

\section{Introduction}

CORONARY Artery Disease (CAD) is a major cause of cardiovascular morbidity and mortality worldwide [1]. The mortality rate from cardiovas-

Correspondence to: Dr. Ghada S. Sabbour, The Department of Clinical Pathology, Ain Shams University, Egypt cular diseases has been predicted to reach $36 \%$ by 2020 [2]. However, its fundamental mechanism is not totally understood till now. CAD is a multifaceted and polygenic illness resulting from interactions between various environmental influences and genetic factors $[3,4]$. CAD is the consequence of several risk factors, such as age, Body Mass Index (BMI), smoking, less exercise, gender, diabetes, hypercholesterolemia. In addition to these risks, it is undeniable that hereditary factors play a crucial role. Both Genome-Wide Association Studies (GWASs) and candidate gene studies have stated that there are numerous genetic variants associated with increased susceptibility to CAD [5,6].

Cytochrome P450 (CYP) enzyme 2J2 (CYP2J2) is one of the predominant CYP epoxygenase isoforms and is abundantly expressed in heart tissue [7]. In endothelial cells and cardiomyocytes, epoxyeicosatrienoic acids (EETs) are predominantly synthesized by CYP2J2 [8], which has been considered a vascular protective factor $[9,10]$. In CYP2J2, the G-50T (CYP2J2-76G >T; *7 allele) polymorphism in the proximal promoter disturbs a Sp 1 transcription factor binding site and brings about less CYP2J2 transcription [11]. Some previous studies have reported that the CYP2J2-50T variant allele was associated with CAD risk [11,12], but at the same time, there are many opposing published results [13-20]. Therefore, the aim of the present case control study was to evaluate the association between the G-50T (CYP2J2*7) (rs890293) gene polymorphism and CAD susceptibility and severity in a cohort of Egyptian individuals.

\section{Subjects and Methods}

Following approval by the "Ethical Committee" of Ain-Shams University and the patients' consents, 
this case control study was carried out in Ain shams University Hospitals in Egypt, during the period from August 2016 to March 2018. The study included a convenient sample of 100 subjects divided into two groups. They were 50 cases (CAD group) and 50 controls (control group). All subjects were from Egypt with both Egyptian parents.

The CAD group included 50 patients with atherosclerotic coronary artery disease confirmed by coronary angiography who were recruited from the Cardiology Department at Ain Shams University Hospitals.

They were further divided into three subgroups based on the number of affected coronary arteries with a significant luminal narrowing of $50 \%$ or more. They were divided into single vessel disease, two vessels disease and multivessel disease.

\section{Exclusion criteria:}

Patients with previous myocardial infarction or previous revascularization.

Patients with end stage renal disease or advanced liver cirrhosis.

The control group was age and sex matched healthy subjects with no clinical evidence of CAD, arterial Hypertension (HTN) or Diabetes Mellitus (DM) or any structural heart disease. They were recruited from other departments. Eligibility criteria for controls: Fully conscious, co-operative, and well-oriented with time, place, and person, who voluntary agree to participate in the study.

2- Methodology: All individuals in this study were subjected to full history taking, thorough clinical examination with special emphasis on cardiac examination and laboratory investigations including: Lipid profile \{Total Cholesterol (TC), Triglycerides (TG), High Density Lipoprotein Cholesterol (HDL-C) and Low Density Lipoprotein Cholesterol (LDL-C) \}, serum urea nitrogen (BUN), serum creatinine and finally G-50T (CYP2J2*7) (rs890293) gene polymorphism genotyping in peripheral blood using Polymerase Chain Reaction and Restriction Fragment Length Polymorphism (PCR-RFLP) technique.

\section{3- Study tools:}

A- Lipid profile (Total cholesterol, TG, HDL$\mathrm{C}$ and LDL-C), BUN and creatinine were performed on Beckman Coulter Au 680 autoanalyzer (Beckman Instruments Inc., Scientific Instruments Division, Inc. 250 S. Kraemer Blvd. Brea, CA926343100 , USA).
B- Genotyping of CYP2J2*7 (G-50T) (rs890293) gene polymorphism was done in peripheral blood using Polymerase Chain Reaction and Restriction Fragment Length Polymorphism (PCRRFLP) technique. Genomic DNA was extracted from EDTA-anticoagulated peripheral whole blood by a GeneJET DNA purification kit supplied by Thermo Scientific (168 Third Avenue, Waltham, MA, USA). Amplification of extracted DNA was done using master mix supplied by Thermo Scientific (168 Third Avenue, Waltham, MA, USA), which contains chemically modified Maxima hot start Taq DNA polymerase, optimized hot start PCR buffer, $\mathrm{Mg}_{+}{ }^{2}$, and dNTPs (deoxynucleotide triphosphates), and the primers supplied by (Applied Biosystems, USA, Inc 850 Lincoln Centre Drive Foster City, CA 94404. USA) with the following sequence: Forward 5"- TTTTCTGAGACCGGTGCGTG-"3 \& reverse 5"- TAGGAGAGTCCGAGGATGGA-“3. PCR amplification started with initial activation of hot start Taq DNA polymerase for 4 minutes at $95^{\circ} \mathrm{C}$, followed by 35 cycles $\left(95^{\circ} \mathrm{C}\right.$ for 30 seconds for DNA denaturation, $58^{\circ} \mathrm{C}$ for 30 seconds for annealing and extension at $72^{\circ} \mathrm{C}$ for 60 seconds) and finished by a final extension step at $72^{\circ} \mathrm{C}$ for 10 minutes. The PCR reaction mixture (total volume 50 L) nontained 20 DNA template, 2 Leach primer and 25 master mix, then molecular-grade $\mathrm{H} 2 \mathrm{O}$ was added at the end to adjust the total volume of the PCR reaction mixture to 50 LCR products were then digested with the restriction enzyme AluI (Fast Digest, Thermo Scientific, 168 Third Avenue, Waltham, MA, USA) at $37^{\circ} \mathrm{C}$ for $15 \mathrm{~min}$ utes.

Finally, the reaction mixture and the DNA ladder (50 base pair (bp)) were loaded on $2 \%$ agarose gel and the DNA fragments were separated by electrophoresis (100 volts for 30 minutes). The subject was considered homozygous mutation if two bands developed at 143-bp and 99-bp, heterozygous mutation if the three bands develop at 242bp, 143-bp and 99-bp and wild type if only one band develops at 242 bp as shown in Fig. (1).

\section{Statistical analysis:}

Data analysis was done using IBM SPSS statistics (V. 22.0, IBM Corp., USA, 2013). Data were expressed descriptively as mean $(\mathrm{X}) \pm$ Standard Deviation (SD) for quantitative parametric data, median and Interquartile Range (IQR) for quantitative non parametric values and as percent for qualitative data. Comparison between two groups in case of parametric data was done using Student's $t$-test while One way ANOVA (analysis of variance) 
was applied for the comparison between more than two groups in case of parametric data. MannWhitney U-test (Wilcoxon Rank-Sum test) was used for statistical comparison between two independent sets of data if one or both of them have a skewed distribution. Kruskal-Wallis test (H-test) was applied for statistical comparison between two or more sets of data if one or more of them have a skewed distribution. As regards the categorized data Chi square test was used for comparison between the independent groups while Fisher's exact test was used instead when the expected frequency was less than 5. $p$-values $>0.05$ indicate a non-significant difference, $p<0.05$ indicates a significant difference, and $p<0.01$ indicates a highly significant difference.

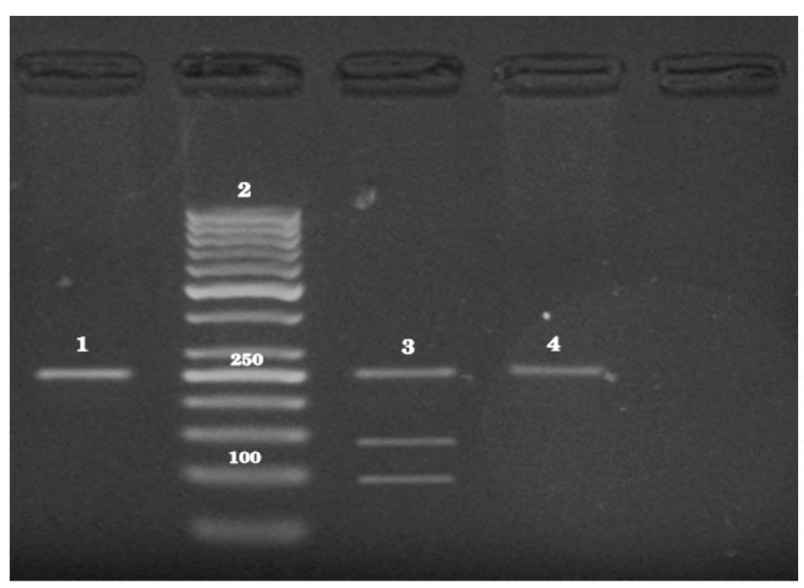

Fig. (1): Gel electrophoresis shows lane 1 and 4 are wild type with a non-digested band at $242 \mathrm{bp}$, lane 2 is a ladder (50bp) and lane 3 with heterozygous mutation of CYP2J2*7 (G50T) with a digested bands at 99bp, 143bp and non-digested band at $242 \mathrm{bp}$.

\section{Results}

Baseline characteristics of study population:

Table (1) showed that both CAD patients and control groups were matched regarding age and gender.

Table (1): Age and gender distribution among study groups.

\begin{tabular}{llcc}
\hline Characteristic & CAD group & Control group & $p$-value \\
\hline Age (years) & $50.78 \pm 12.04$ & $54.24 \pm 9.46$ & 0.113 \\
Gender: & & & \\
Male & $43(68 \%)$ & $41(82 \%)$ & 0.106 \\
Female & $16(32 \%)$ & $9(18 \%)$ & \\
\hline
\end{tabular}

\section{Clinical characteristics of the study populations:}

Baseline characteristics of CAD patients are summarized in (Table 2).

Table (2): Clinical and laboratory characteristics of study population.

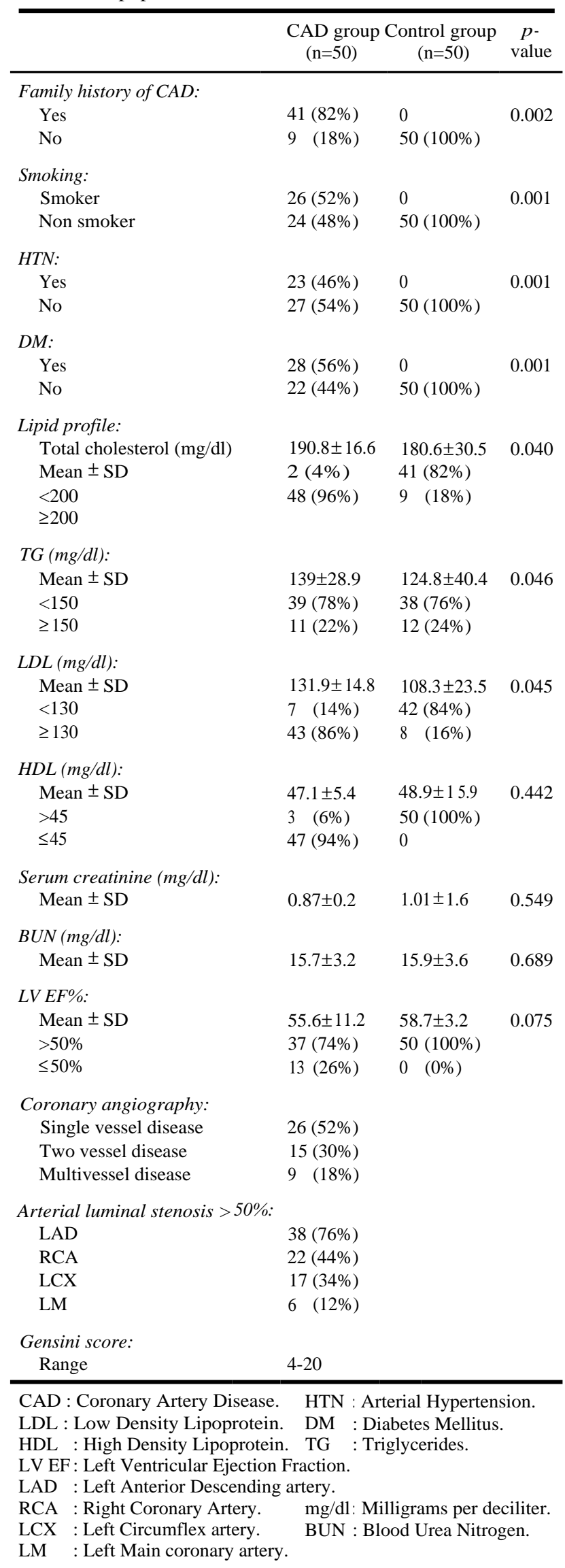


Laboratory investigations among study population are also summarized in (Table 2). There was a highly significant level of total cholesterol, LDL, triglyceride ( $p$-value <0.05) in patient of CAD group compared to the control group.

Genotype distribution among the studied population:

In the CAD group: $96 \%$ of the patients $(n=48)$ were GG genotype, $4 \%$ of the patients $(n=2)$ were GT genotype and no patients were TT genotype. While in the control group, all subjects were GG genotype $(100 \%)$. But there was no significant statistical difference in the genotype distribution of GG genotype, GT genotype and TT genotype between the two groups ( $p$-value $=0.115)$.

As regard Allele frequencies of the CYP $2 \mathrm{~J} 2 * 7$ gene SNP (G50T), G allele was found in 98 (98\%) patients in the CAD group while $\mathrm{T}$ allele was found in only two patients (2\%). In the control group, $\mathrm{G}$ allele was found in all subjects $(100 \%)$. But, there was no significant statistical difference in the $\mathrm{G}$ and $\mathrm{T}$ allele frequency between $\mathrm{CAD}$ group and control group ( $p$-value $=0.153)$ as shown in (Table 3).

Table (3): Distribution of CYP 2J2*7 gene SNP (G50T) alleles and genotypes in CHD patients and healthy controls.

\begin{tabular}{|c|c|c|c|}
\hline $\begin{array}{l}\text { G-50T }(\text { CYP2J2*7) }(\mathrm{rs} 890293) \\
\text { gene polymorphism }\end{array}$ & $\begin{array}{l}\text { CAD group } \\
\quad(n=50)\end{array}$ & $\begin{array}{c}\text { Control group } \\
\qquad(\mathrm{n}=50)\end{array}$ & $\begin{array}{c}p- \\
\text { value }\end{array}$ \\
\hline \multicolumn{4}{|l|}{ Alleles $(n=100)$ : } \\
\hline $\mathrm{G}$ & $98(98 \%)$ & $100(100 \%)$ & 0.153 \\
\hline $\mathrm{T}$ & $2(2 \%)$ & $0 \quad(0 \%)$ & \\
\hline \multicolumn{4}{|l|}{ Genotypes: } \\
\hline GG & $48(96 \%)$ & $50(100 \%)$ & 0.115 \\
\hline GT & $2(4 \%)$ & $0(0 \%)$ & \\
\hline TT & $\begin{array}{ll}0 & (0 \%)\end{array}$ & $0(0 \%)$ & \\
\hline
\end{tabular}

In the CAD group, $95.1 \%(n=39)$ of males were GG genotype and $4.8 \%(n=2)$ were GT genotype. On the other hand $100 \%(n=9)$ of females were GG genotype. But there was no significant statistical difference in the genotype frequency in males and females $(p$-value $=0.49)$ (Table 4$)$.

We found that 27 out of 28 diabetic patients were GG genotype while only one patient was GT genotype. 22 out of 23 hypertensive patients were GG genotype while only one patient was GT genotype. All smokers and all patients with family history of CAD were GG genotype (Table 4).

Regarding lipid profile, there was no statistically difference between GG genotype patients and GT genotype patients $(p$-value $>0.05)$ as shown in (Table 4).
Table (4): Relation between G-50T (CYP2J2*7) (rs890293) genotype polymorphism and clinical characteristics of CAD patients.

\begin{tabular}{|c|c|c|c|}
\hline CAD group $(n=50)$ & GG $(n=48)$ & GT $(n=2)$ & $p$-value \\
\hline Age & $53.92 \pm 9.34$ & $62.00 \pm 12.73$ & 0.241 \\
\hline \multicolumn{4}{|l|}{ Gender: } \\
\hline Males & $39(95.1 \%)$ & $2(4.8 \%)$ & \multirow[t]{2}{*}{0.49} \\
\hline Females & $9(100 \%)$ & $0(0 \%)$ & \\
\hline \multicolumn{4}{|l|}{ Family history of CAD1: } \\
\hline Yes & $9(18.8 \%)$ & $0(0 \%)$ & \multirow[t]{2}{*}{0.49} \\
\hline No & $39(81.2 \%)$ & $2(100 \%)$ & \\
\hline \multicolumn{4}{|l|}{ Smoking: } \\
\hline Smoker & $26(54.2 \%)$ & $2(100 \%)$ & \multirow{2}{*}{0.13} \\
\hline Non smoker & $22(45.8 \%)$ & $0(0 \%)$ & \\
\hline \multicolumn{4}{|l|}{$H T N:$} \\
\hline Yes & $22(45.8 \%)$ & $1(50 \%)$ & \multirow{2}{*}{0.908} \\
\hline No & $26(54.2 \%)$ & $1(50 \%)$ & \\
\hline \multicolumn{4}{|l|}{$D M:$} \\
\hline Yes & $27(56.2 \%)$ & $1(50 \%)$ & \multirow[t]{2}{*}{0.861} \\
\hline No & $21(43.8 \%)$ & $1(50 \%)$ & \\
\hline \multicolumn{4}{|l|}{$\begin{array}{l}\text { Lipid profile: } \\
\text { - Total cholesterol }(\mathrm{mg} / \mathrm{dl}) \text { : }\end{array}$} \\
\hline Mean \pm SD & $191.02 \pm 16.53$ & $185.50 \pm 23.33$ & \multirow{3}{*}{$\begin{array}{l}0.649 \\
0.237\end{array}$} \\
\hline$<200$ & $41(85.4 \%)$ & $1(50 \%)$ & \\
\hline$\geq 200$ & $7 \quad(14.5 \%)$ & $1(50 \%)$ & \\
\hline \multicolumn{4}{|l|}{ - $T G(m g / d l):$} \\
\hline Mean \pm SD & $138.65 \pm 29.41$ & $147.50 \pm 16.26$ & 0.676 \\
\hline$<150$ & $37(77.1 \%)$ & $2(100 \%)$ & \multirow{2}{*}{0.745} \\
\hline$\geq 150$ & $11(22.9 \%)$ & $0(0 \%)$ & \\
\hline \multicolumn{4}{|l|}{ - $L D L(m g / d l):$} \\
\hline Mean \pm SD & $130.19 \pm 14.65$ & $125.50 \pm 23.33$ & 0.478 \\
\hline$<130$ & $7 \quad(14.5 \%)$ & $0(0 \%)$ & \multirow[t]{2}{*}{0.560} \\
\hline$\geq 130$ & $41(85.4 \%)$ & $2(100 \%)$ & \\
\hline \multicolumn{4}{|l|}{ - $H D L(m g / d l):$} \\
\hline Mean \pm SD & $47.08 \pm 5.50$ & $47.50 \pm 3.54$ & 0.916 \\
\hline$>45$ & $45(93.7 \%)$ & $2(100 \%)$ & \multirow[t]{2}{*}{0.715} \\
\hline$\leq 45$ & $3 \quad(6.3 \%)$ & $0(0 \%)$ & \\
\hline Serum creatinine $(\mathrm{mg} / \mathrm{dl})$ : & & & \\
\hline Mean $\pm S D$ & $0.86 \pm 0.19$ & $0.95 \pm 0.21$ & 0.530 \\
\hline BUN $(\mathrm{mg} / \mathrm{dl}):$ & & & \\
\hline Mean \pm SD & $15.71 \pm 3.25$ & $14.50 \pm 3.54$ & 0.610 \\
\hline LVEF\%: & & & \\
\hline Mean \pm SD & $56.02 \pm 11.17$ & $45.50 \pm 7.78$ & 0.196 \\
\hline$>50 \%$ & $36(75 \%)$ & $1(50 \%)$ & 0.430 \\
\hline$\leq 50 \%$ & $12(25 \%)$ & $1(50 \%)$ & \\
\hline Coronary angiography: & & & \\
\hline Single vessel disease & $26(54.2 \%)$ & $0(0 \%)$ & 0.280 \\
\hline Two vessel disease & $14(29.2 \%)$ & $1(50 \%)$ & \\
\hline Multivessel disease & $8(16.7 \%)$ & $1(50 \%)$ & \\
\hline $\begin{array}{l}\text { Arterial luminal stenosis } \\
>50 \% \text { : }\end{array}$ & & & \\
\hline LAD & $36(75 \%)$ & $2(100 \%)$ & 0.417 \\
\hline RCA & $20(41.7 \%)$ & $2(100 \%)$ & 0.103 \\
\hline LCX & $17(35.4 \%)$ & $1(50 \%)$ & 0.626 \\
\hline LM & $5 \quad(10.4 \%)$ & $0(0 \%)$ & 0.630 \\
\hline Gensini score: & & & \\
\hline Range/median & $2-20 / 12$ & $8-40 / 24$ & 0.441 \\
\hline CAD : Coron & ease HTN & terial Hyperten & sion. \\
\hline & & riglycerides. & \\
\hline $\begin{array}{l}\text { LDL : Low Density Lipo } \\
\mathrm{mg} / \mathrm{dl}: \text { Milligrams per de }\end{array}$ & $\begin{array}{l}\text { rotein. HDL: } 1 \\
\text { iliter. BUN : } 1\end{array}$ & $\begin{array}{l}\text { Iigh Density Lip } \\
\text { lood Urea Nitros }\end{array}$ & $\begin{array}{l}\text { oprotein. } \\
\text { gen. }\end{array}$ \\
\hline LV EF : Left Ventricular E & jection Fraction. & & \\
\hline LAD : Left Anterior Des & ending artery. & & \\
\hline RCA : Right Coronary A & tery. & & \\
\hline LCX : Left Circumflex at & tery. & eft Main coronar & ry artery. \\
\hline
\end{tabular}


Table (5): Clinical and laboratory characteristics of subgroups of the patient group.

\begin{tabular}{|c|c|c|c|c|}
\hline & $\begin{array}{l}\text { Single } \\
\text { vessel } \\
\text { disease } \\
(n=26)\end{array}$ & $\begin{array}{c}\text { Two } \\
\text { vessel } \\
\text { disease } \\
(\mathrm{n}=15)\end{array}$ & $\begin{array}{l}\text { Multi- } \\
\text { vessel } \\
\text { disease } \\
(\mathrm{n}=9)\end{array}$ & $\begin{array}{c}p- \\
\text { value }\end{array}$ \\
\hline Age (years) & $52.5 \pm 10.1$ & $55.5 \pm 7.8$ & $57.3 \pm 10.3$ & 0.352 \\
\hline $\begin{array}{l}\text { Gender: } \\
\quad \text { Males } \\
\text { Females }\end{array}$ & $\begin{array}{l}21(80.8 \%) \\
5 \quad(19.2 \%)\end{array}$ & $\begin{array}{l}12(80 \%) \\
3 \quad(20 \%)\end{array}$ & $\begin{array}{l}8(89 \%) \\
1(11 \%)\end{array}$ & 0.837 \\
\hline $\begin{array}{l}\text { Family history of } \\
\text { CAD: } \\
\text { Yes } \\
\text { No }\end{array}$ & $\begin{array}{l}4 \quad(15.4 \%) \\
22(84.6 \%)\end{array}$ & $\begin{array}{l}3 \quad(20 \%) \\
12(80 \%)\end{array}$ & $\begin{array}{l}2(22.2 \%) \\
7(77.8 \%)\end{array}$ & 0.874 \\
\hline $\begin{array}{l}\text { Smoking: } \\
\text { Smoker } \\
\text { Non smoker }\end{array}$ & $\begin{array}{l}15(57.7 \%) \\
11(42.3 \%)\end{array}$ & $\begin{array}{l}4(26.7 \%) \\
11(73.3 \%)\end{array}$ & $\begin{array}{l}7(77.8 \%) \\
2(22.2 \%)\end{array}$ & 0.037 \\
\hline $\begin{array}{l}H T N: \\
\text { Yes } \\
\text { No }\end{array}$ & $\begin{array}{l}12(46.2 \%) \\
14(53.8 \%)\end{array}$ & $\begin{array}{l}7(46.7 \%) \\
8(53.3 \%)\end{array}$ & $\begin{array}{l}4(44.4 \%) \\
5(55.6 \%)\end{array}$ & 0.994 \\
\hline $\begin{array}{l}D M: \\
\text { Yes } \\
\text { No }\end{array}$ & $\begin{array}{l}12(46.2 \%) \\
14(53.8 \%)\end{array}$ & $\begin{array}{l}12(80 \%) \\
3 \quad(20 \%)\end{array}$ & $\begin{array}{l}4(44.4 \%) \\
5(55.6 \%)\end{array}$ & 0.081 \\
\hline $\begin{array}{l}\text { Lipid profile: } \\
\text { - Total cholesterol } \\
\text { (mg/dl): } \\
\quad \text { Mean } \pm \text { SD } \\
\quad<200 \\
\geq 200\end{array}$ & $\begin{array}{l}188.4 \pm 12.1 \\
24(92.3 \%) \\
2 \quad(7.7 \%)\end{array}$ & $\begin{array}{l}197.7 \pm 20.5 \\
11(73.3 \%) \\
4 \quad(26.7 \%)\end{array}$ & $\begin{array}{l}186.1 \pm 18.7 \\
7(77.8 \%) \\
2(22.2 \%)\end{array}$ & $\begin{array}{l}0.145 \\
0.176\end{array}$ \\
\hline $\begin{array}{l}T G(m g / d l): \\
\text { Mean } \pm \text { SD } \\
<150 \\
\geq 150\end{array}$ & $\begin{array}{l}133.3 \pm 20.5 \\
22(84.6 \%) \\
4 \quad(15.4 \%)\end{array}$ & $\begin{array}{l}152.3 \pm 40.4 \\
11(73.3 \%) \\
4 \quad(26.7 \%)\end{array}$ & $\begin{array}{l}133.4 \pm 22.1 \\
6(66.7 \%) \\
3(33.3 \%)\end{array}$ & $\begin{array}{l}0.104 \\
0.167\end{array}$ \\
\hline $\begin{array}{l}\text { - } L D L(m g / d l): \\
\quad \text { Mean } \pm \text { SD } \\
\quad<130 \\
\geq 130\end{array}$ & $\begin{array}{l}130.7 \pm 11.2 \\
3 \quad(11.5 \%) \\
23(88.5 \%)\end{array}$ & $\begin{array}{l}136.4 \pm 15.9 \\
2 \quad(13.3 \%) \\
13(86.7 \%)\end{array}$ & $\begin{array}{l}133.4 \pm 21.2 \\
2(22.2 \%) \\
7(77.8 \%)\end{array}$ & $\begin{array}{l}0.494 \\
0.726\end{array}$ \\
\hline $\begin{array}{l}\text { - } H D L(m g / d l): \\
\quad \text { Mean } \pm \text { SD } \\
>45 \\
\leq 45\end{array}$ & $\begin{array}{l}48 \pm 4.34 \\
26(100 \%) \\
0(0 \%)\end{array}$ & $\begin{array}{l}47.9 \pm 5.1 \\
14(93.3 \%) \\
1 \quad(6.7 \%)\end{array}$ & $\begin{array}{l}43.2 \pm 7.43 \\
7(77.8 \%) \\
2(22.2 \%)\end{array}$ & $\begin{array}{l}0.057 \\
0.053\end{array}$ \\
\hline $\begin{array}{l}\text { Serum creatinine } \\
(m g / d l): \\
\quad \text { Mean } \pm \text { SD }\end{array}$ & $0.87 \pm 0.19$ & $0.83 \pm 0.17$ & $0.94 \pm 0.19$ & 0.343 \\
\hline $\begin{array}{l}B U N(m g / d l): \\
\quad \text { Mean } \pm \text { SD }\end{array}$ & $16.19 \pm 3.20$ & $14.73 \pm 3.26$ & $15.67 \pm 3.32$ & 0.388 \\
\hline $\begin{array}{l}L V E F \%: \\
\quad \text { Mean } \pm \text { SD } \\
>50 \% \\
\leq 50 \%\end{array}$ & $\begin{array}{l}57.92 \pm 9.84 \\
22(84.6 \%) \\
4 \quad(15.4 \%)\end{array}$ & $\begin{array}{l}53.13 \pm 12.05 \\
9(60 \%) \\
6(40 \%)\end{array}$ & $\begin{array}{l}53.00 \pm 13.17 \\
6(66.7 \%) \\
3(33.3 \%)\end{array}$ & $\begin{array}{l}0.317 \\
0.192\end{array}$ \\
\hline $\begin{array}{l}\text { Arterial luminal } \\
\text { stenosis }>50 \% \text { by } \\
\text { coronary } \\
\text { angiography: } \\
\text { LAD } \\
\text { RCA } \\
\text { LCX } \\
\text { LM }\end{array}$ & $\begin{array}{ll}17 & (65.4 \%) \\
8 & (30.8 \%) \\
1 & (3.8 \%) \\
0 & (0 \%)\end{array}$ & $\begin{array}{l}12(80 \%) \\
8(53.3 \%) \\
8(53.3 \%) \\
2(13.3 \%)\end{array}$ & $\begin{array}{l}9(100 \%) \\
6(66.7 \%) \\
9(100 \%) \\
3(33.3 \%)\end{array}$ & $\begin{array}{l}0.101 \\
0.119 \\
0.000 \\
0.014\end{array}$ \\
\hline $\begin{array}{l}\text { Gensini score: } \\
\text { Range/median }\end{array}$ & $3-6 / 5$ & $12-20 / 14$ & $28-120 / 39$ & 0.000 \\
\hline $\begin{array}{l}\text { CAD : Coronary } \\
\text { DM : Diabetes } \\
\text { LDL : Low Dens } \\
\text { mg/dl : Milligram } \\
\text { LV EF : Left Ventr } \\
\text { LAD : Left Anter } \\
\text { RCA : Right Coro } \\
\text { LCX : Left Circu }\end{array}$ & $\begin{array}{l}\text { llitus. } \\
\text { y Lipoprotein } \\
\text { per deciliter. } \\
\text { ular Ejection } \\
\text { r Descending } \\
\text { ary Artery. } \\
\text { flex artery. }\end{array}$ & $\begin{array}{l}\text { HTN : Arte } \\
\text { TG : Trig } \\
\text { HDL : Hig } \\
\text { BUN : Blo } \\
\text { Fraction. } \\
\text { artery. }\end{array}$ & $\begin{array}{l}\text { Density Lipop } \\
\text { od Urea Nitrog }\end{array}$ & $\begin{array}{l}\text { ion. } \\
\text { rotein. } \\
\text { en. } \\
\text { artery. }\end{array}$ \\
\hline
\end{tabular}

\section{Subgroup analysis in CAD group:}

Risk factors for CAD and laboratory details for subgroups are depicted in (Table 5).

$100 \%$ of patients with single vessel disease $(\mathrm{n}=$ 26) were GG genotype. $93.3 \%$ of patients with two vessel disease $(\mathrm{n}=14)$ were GG genotype and $6.7 \%$ $(\mathrm{n}=1)$ were GT genotype. While $88.9 \%$ of patients with multivessel disease $(n=8)$ were $\mathrm{GG}$ genotype and $11.1 \%(n=1)$ were GT genotype. There was no significant statistical difference in the genotype distribution of patients with single vessel disease when compared to patients with two vessel and multi vessel coronary artery disease $(p$-value $=0.28)$ as shown in (Table 6).

As regard Allele Frequencies, $\mathrm{G}$ allele was found in all patients $(100 \%)$ with single vessel disease. While $\mathrm{G}$ allele was found in $96.7 \%$ of patients with two vessel disease $(n=29)$ and $T$ allele was found in only one patient (3.3\%). In patients with multivessel disease, $\mathrm{G}$ allele was found in $94.4 \%$ of patients $(n=17)$ and $T$ allele was found in only one patient $(5.6 \%)$. But, there was no significant statistical difference in the $\mathrm{G}$ and $\mathrm{T}$ allele frequency among the three subgroups ( $p$ value $=0.28)$ (Table 6).

Table (6): Distribution of CYP 2J2*7 gene SNP (G50T) alleles and genotypes in subgroups of CAD patients.

\begin{tabular}{|c|c|c|c|}
\hline $\begin{array}{l}\text { G-50T }(\text { CYP2J2*7) } \\
\text { (rs890293) gene } \\
\text { polymorphism }\end{array}$ & $\begin{array}{l}\text { Single vessel } \\
\text { disease } \\
(n=26)\end{array}$ & $\begin{array}{l}\text { Two vessel } \\
\text { disease } \\
(n=15)\end{array}$ & $\begin{array}{c}p- \\
\text { value }\end{array}$ \\
\hline \multicolumn{4}{|l|}{ Alleles: } \\
\hline G & $52(100 \%)$ & $29(96.7 \%)$ & 0.280 \\
\hline $\mathrm{T}$ & $0 \quad(0 \%)$ & $1 \quad(3.3 \%)$ & \\
\hline \multicolumn{4}{|l|}{ Genotypes: } \\
\hline GG & $26(100 \%)$ & $14(93.3 \%)$ & 0.287 \\
\hline GT & $0 \quad(0 \%)$ & $1 \quad(6.7 \%)$ & \\
\hline kTT & $0 \quad(0 \%)$ & $0 \quad(0 \%)$ & \\
\hline
\end{tabular}

\section{Discussion}

CYP2J2 gene, is a unique member of the $2 \mathrm{~J}$ subfamily of cytochrome P450-containing epoxygenases [21]. Cytochrome P450 (CYP) enzyme 2J2 (CYP2J2) is one of the predominant CYP epoxygenase isoforms and is abundantly expressed in heart tissue, endothelial cells and cardiomyocytes. EETs, synthesized by CYP2J2, have many important physiological actions including maintaining cardiomyocyte viability suffering from damaging stimuli and enhance the recovery of cells from oxygen deprivation [22].

In CYP2J2, the G-50T SNP (rs890293) in the proximal promoter disturbs a $\mathrm{Sp} 1$ transcription factor binding site with a considerable decrease in 
activity of the promoter in the CYP2J2 gene, followed by a decrease in CYP2J2 protein and EETs generation [23].

In view of the above data, the study aimed to investigate the clinical utility of the CYP $2 \mathrm{~J} 2 * 7$ gene polymorphism (G-50T) (rs890293) in a cohort of Egyptian individuals in order to explore their association with CAD susceptibility or its severity. The study was conducted on 100 subjects included 50 CAD patients and 50 age and sex matched apparently healthy control subjects at Ain Shams University Hospitals.

The current study revealed that the genotypic and allelic frequencies of G-50T were not statistically significant different between CAD patients' group and the control group ( $p=0.115$ and 0.153 , respectively). These results are in agreement with those of Zhu et al., [13] and Chen et al., [24] done on Chinese population.

Zhu et al., [13] reported that CYP2J2*7 (G50T) polymorphism did not reveal a significant role in the development of coronary artery disease and myocardial infarction by being present in $8.9 \%$ (51/521) of CAD patients versus $9.7 \%$ (44/411) in the control group.

On the contrary to our study, Spiecker et al., [11] who studied the association between CYP2J2*7 (G-50T) polymorphism and coronary artery disease in German population and reported a significant association between CYP2J2*7 polymorphism (G50T) and coronary artery disease being present in $17.3 \%(50 / 289)$ of CAD patients versus $10.6 \%$ $(27 / 255)$ in the control group. Also, a study on Taiwanese population performed by Yen et al., [25] showed a significant association between CYP$2 \mathrm{~J} 2 * 7$ (G-50T) polymorphism and premature MI being present in $32 \%(64 / 200)$ of MI patients versus $22 \%(44 / 200)$ in control group. Moreover, they reported that in vascular endothelial cells, the (G$50 \mathrm{~T})$ polymorphism was associated with a $50 \%$ reduction in CYP2J2 promoter activity compared with that of the wild type promoter. As a consequence, individuals with the CYP2J2*7 (G-50T) polymorphism had significantly lower plasma (EETs), compared to wild type individuals $[11,25]$.

Lee et al., [17] investigated the association between CYP2J2 (G-50T) polymorphism and CAD and reported that the CYP2J2 G-50T polymorphism was associated with significantly lower risk of coronary artery disease in African-Americans however, no significant association was observed in Caucasians.
The discrepancies of results between our study and those of the mentioned researchers may be attributed not only to different study designs and sample sizes but also to the ethnic variation. Moreover, it became evident that single-locus effects cannot explain multifactorial chronic diseases. Thus, when the single polymorphism effect is not present alone or is not strong enough, it is important to characterize the other gene polymorphisms related to susceptibility. Another explanation for that discrepancy was given by Sato et al., [26] who reported that reduced P450-mediated EETs biosynthesis could have protective effects against the development of CAD clinical events. They also stated that despite the well-characterized vasodilator and anti-inflammatory effects of EETs, evidence has demonstrated that increased EETs generation also significantly increases Matrix Metalloproteinases (MMPs) enzyme activity in endothelial cells. The matrix metalloproteinase are potent stimulators of vascular remodeling and atherosclerotic plaque destabilization, and are integrally involved in the precipitation of plaque rupture and acute cardiovascular events [26]

Furthermore, the current study did not find any significant association of G50T genotypes and alleles with smoking, hypertension, diabetes mellitus as well as, hyperlipidemia and positive family history of CAD in the study population. In that respect, these results are in accordance with those previously obtained by Zhu et al., [13] .

One of the main aims of the current study was to clarify if there is an association between CYP2J2*7 (G-50T) SNP and CAD disease severity. The current study revealed a non-significant association of the G-50T genotypes and alleles with CAD severity neither with the number of atherosclerotic coronaries nor with Gensini score. In accordance with our findings, Lung et al., [16] had reported that there was no consistent relationship between the G50T genotypes and alleles and the number of significantly diseased coronaries. Addition of Gensini score may add better assessment for severity of CAD in each patient in the current study than numbering only significant diseased coronaries.

\section{Conclusion:}

Our study had demonstrated that there was no significant association between CYP2J2*7 gene polymorphism (G-50T) (rs890293) and risk of coronary artery disease and also no association between this gene polymorphism and the severity of CAD in the sample of Egyptian population included in this study. 


\section{Declaration of conflicting interests:}

The authors declared no conflicts of interest with respect to the authorship and/or publication of this article.

Funding: This research did not receive any specific grant from any funding agency in the public, commercial or not-for-profit sector.

\section{References}

1- LOPEZ A.D., MATHERS C.D., EZZATI M., JAMISON D.T. and MURRAY C.J.: Global and regional burden of disease and risk factors, 2001: Systematic analysis of population health data. Lancet, 367: 1747-57, 2006.

2- DARIUSH M., EMELIA J., BENJAMIN A., DONNA K., ARNETT M. and BLAHA M.: Turner and on behalf of the American Heart Association Statistics Committee and Stroke Statistics Subcommittee. Circulation, 122: 20223, 2016.

3- SUN J., QIAN Y., JIANG Y., CHEN J., DAI J., JIN G., WANG J., HU Z., LIU S., SHEN C. and SHEN H.: Association of KCTD10, MVK, and MMAB polymorphisms with dyslipidemia and coronary heart disease in Han Chinese population. Lipids Health Dis., 15: 171. 3, 2016.

4- WUNG S.F., HICKEY K.T., TAYLOR J.Y. and GALLEK M.J.: Cardiovascular genomics. J. Nurs. Scholarsh., 45: 60-8, 2013.

5- NIKPAY M., GOEL A., WON H.H., HALL L.M., WILLENBORG C., KANONI S., SALEHEEN D., KYRIAKOU T., NELSON C.P., HOPEWELL J.C., WEBB T.R., ZENG L., DEHGHAN A., et al.: A comprehensive 1,000 Genomes-based genome-wide association meta-analysis of coronary artery disease. Nat Genet., 47: 1121-30. 5, 2015.

6- CHO E.Y., JANG Y., SHIN E.S., JANG H.Y., YOO Y.K., KIM S., JANG J.H., LEE J.Y., YUN M.H., PARK M.Y., CHAE J.S., LIM J.W., SHIN D.J., et al.: Genome-wide association analysis and replication of coronary artery disease in South Korea suggests a causal variant common to diverse populations. Heart Asia, 2: 104-8, 2010.

7- WU S., MOOMAW C.R., TOMER K.B., FALCK J.R. and ZELDIN D.C.: Molecular cloning and expression of CYP2J2, a human cytochrome $\mathrm{P} 450$ arachidonic acid epoxygenase highly expressed in heart. J. Biol. Chem., 271: 3460-8, 1996.

8- ZELDIN D.C.: Epoxygenase pathways of arachidonic acid metabolism. J. Biol. Chem., 276: 36059-62. 8, 2001.

9- NODE K., RUAN X.L., DAI J., YANG S.X., GRAHAM L., ZELDIN D.C. and LIAO J.K.: Activation of Galpha $\mathrm{s}$ mediates induction of tissue-type plasminogen activator gene transcription by epoxyeicosatrienoic acids. J. Biol. Chem., 276: 15983-9, 2001.

10- CAMPBELL W.B., GEBREMEDHIN D., PRATT P.F. and HARDER D.R.: Identification of epoxyeicosatrienoic acids as endotheliumderived hyperpolarizing factors. Circ. Res., 78: 415-23, 1996.

11- SPIECKER M., DARIUS H., HANKELN T., SOUFI M., SATTLER A.M., SCHAEFER J.R., NODE K., BORGEL J., MUGGE A., LINDPAINTNER K., HUESING A.,
MAISCH B., ZELDIN D.C., et al.: Risk of coronary artery disease associated with polymorphism of the cytochrome P450 epoxygenase CYP2J2. Circulation, 110: 2132-6, 2004.

12- LIU P.Y., LI Y.H., CHAO T.H., WU H.L., LIN L.J., TSAI L.M. and CHEN J.H.: Synergistic effect of cytochrome P450 epoxygenase CYP2J2*7 polymorphism with smoking on the onset of premature myocardial infarction. Atherosclerosis, 195: 199-206, 2007.

13- ZHU Q., FU Z., MA Y., YANG H., HUANG D., XIE X., LIU F., ZHENG Y. and CHA E.: A novel polymorphism of the CYP2J2 gene is associated with coronary artery disease in Uygur population in China. Clin. Biochem., 46: 1047-54, 2013.

14- XU Y., DING H., PENG J., CUI G., LIU L., CIANFLONE K. and WANG D.W.: Association between polymorphisms of CYP2J2 and EPHX2 genes and risk of coronary artery disease. Pharmacogenet. Genomics., 21: 489-94, 2011.

15- TZVEOVA R., NAYDENOVA G., YANEVA T., DIMITROV G., VANDEVA S., MATROZOVA Y., PENDICHEVA-DUHLENSKA D., POPOV I., BELTHEVA O., NAYDENOV C., TARNOVSKA-KADREVA R., NACHEV G., MITEV V., et al.: Gender-Specific Effect of CYP2C8*3 on the Risk of Essential Hypertension in Bulgarian Patients. Biochem. Genet., 53: 319-33, 2015.

16- LUNG A., YU L., CHI J., CHUN L. and CHI T.: G-50T Polymorphism of the cytochrome $\mathrm{P} 450$ epoxygenase CYP2J2 gene is not associated with the risk of coronary artery disease among Chinese in Taiwan. Acta Cardiol. Sin., 22: 148-53, 2006.

17- LEE C.R., NORTH K.E., BRAY M.S., COUPER D.J., HEISS G. and ZELDIN D.C.: CYP2J2 and CYP2C8 polymorphisms and coronary heart disease risk: The Atherosclerosis Risk in Communities (ARIC) study. Pharmacogenet Genomics, 17: 349-58, 2007.

18- HOFFMANN M.M., BUGERT P., SEELHORST U., WELLNITZ B., WINKELMANN B.R., BOEHM B.O. and MARZ W.: The $-50 \mathrm{G}>\mathrm{T}$ polymorphism in the promoter of the CYP2J2 gene in coronary heart disease: The Ludwigshafen Risk and Cardiovascular Health study. Clin. Chem., 53: 539-40, 2007.

19- FAVA C., MONTAGNANA M., ALMGREN P., HEDBLAD B., ENGSTROM G., BERGLUND G., MINUZ P. and MELANDER O.: The common functional polymorphism $-50 \mathrm{G}>\mathrm{T}$ of the CYP2J2 gene is not associated with ischemic coronary and cerebrovascular events in an urban-based sample of Swedes. J. Hypertens, 28: 294-9, 2010.

20- ARUN KUMAR A.S., KUMAR S.S., UMAMAHESWARAN G., KESAVAN R., BALACHANDAR J. and ADITHAN C.: Association of CYP2C8, CYP2C9 and CYP2J2 gene polymorphisms with myocardial infarction in South Indian population. Pharmacol. Rep., 67: 97-101, 2015.

21- GUENGERICH F.P. and CHENG Q.: Orphans in the human cytochrome P450 superfamily: Approaches to discovering functions and relevance in pharmacology. Pharmacological Reviews, 63 (3): 684-99, 2011.

22- YANG B., GRAHAM L., DIKALOV S., MASON R.P., FALCK J.R., LIAO J.K. and ZELDIN D.C.: Overexpression of cytochrome P450 CYP2J2 protects against hypoxia- 
reoxygenation injury in cultured bovine aortic endothelial cells. Mol. Pharmacol., 60: 310-20, 2001.

23- CAMPBELL W.B., GEBREMEDHIN D., PRATT P.F. and HARDER D.R.: Identification of epoxyeicosatrienoic acids as endothelium-derived hyperpolarizing factors. Circ. Res., 78: 415-23, 2014.

24- CHEN J., DONG W., GUO F., JIE D., LEI Y., et al.: Metaanalysis of the association of the CYP2J2 G-50T polymorphism with coronary artery disease. Oncotarget, 8 : 59618-27, 2017.
25- YEN P., LIU A., YI-HENG L., TING-HSING C., HUALIN W., LI-JEN L., LIANG-MIIN T. and JYH-HONG C.: Synergistic effect of cytochrome $\mathrm{P} 450$ epoxygenase CYP2J2*7 polymorphism with smoking on the onset of premature myocardial infarction. Atherosclerosis, 195: 199-206, 2007.

26- SHAH K., SHALIA K., MASHRU R., SONEJI L., ABRAHAM A., KUDALKAR V., VASVANI B. and SANGHAVI T.: Role of matrix metalloproteinases in coronary artery disease. Indian Heart J., 61: 44-50, 2011.

\section{G-50T (CYP2J2) تقييم إرتباط تعلد آشكال جين الشين

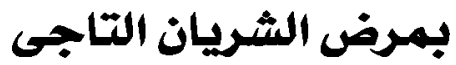

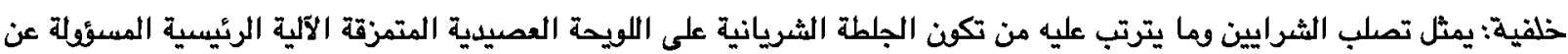

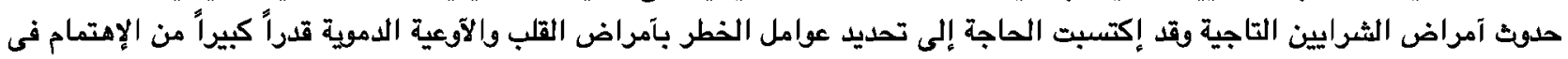

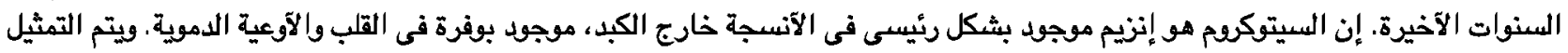

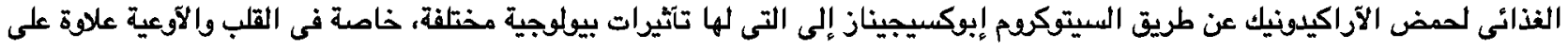
ذلك، إنه موجود بدرجة كبيرة فى الخلايا الدموية.

$$
\text { الهدف: هدفت الدراسة الحالية إلى تقييم إرتباط تعدد آشكال جين G-50T (CYP2J2) بمرض الشريان التاجى. }
$$

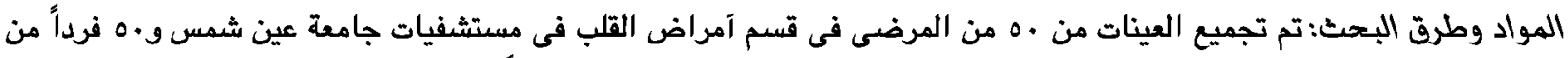

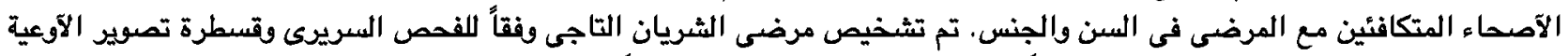

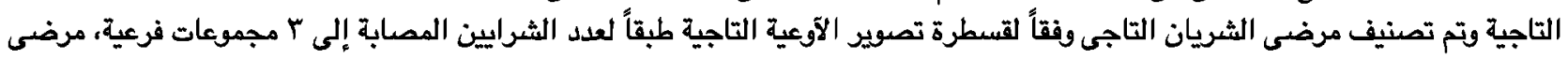

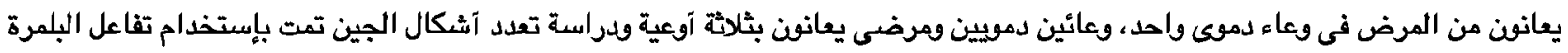

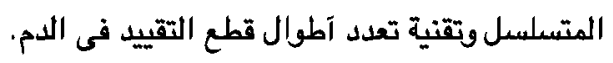
النتائج:وكثفت نتائجنا آن الشكل الجينى T والنسخة الجينية G-50T (CYP2J2 لم يظهرا إرتباط نو دلالة إحصائية بمرض الشريان

الخلاصة: في الختام، آظهرت دراستنا عدم وجود إرتباط ذو دلالة إحصائية بين تعدد الآشكال الجينية ووجود وشدة مرض الشريان التاجى فى عينة المصريين المدرجة فى دراستنا. 